\title{
Penetration of Fire into Iron
}

The Sense and the Usage Mode of This Metaphor for Description of Theosis in the Byzantine Theological Literature

\author{
Dmitry Biriukov \\ National Research University Higher School of Economics (HSE) \\ dbirjuk@gmail.com
}

\begin{abstract}
I consider the ways whereby the Stoic natural philosophical paradigm of total blending, through the example of penetration of fire into iron, was naturalized by the Early Christian and Byzantine theologians who intended to display the penetration of the divine into the created and the conjunction of the created with the divine, with the condition that the created does not dissolve in divine but remains within its own nature being penetrated by the properties of deity.
\end{abstract}

\section{Keywords}

theosis - total blending - participation - impartation of properties - recognition

The Stoic doctrine on mixture and an example of penetration of fire into iron in the Christian literature: typology. ${ }^{1}$

The example of iron and fire as an illustration of interpenetration of bodies traces its origins to a Stoic doctrine. ${ }^{2}$ The Stoics gave this example along with a number of others for substantiating their teaching on total blending of bodies (in its difference from conflation and composition). Compliant to Stoics, the blending $\left(\mu^{\prime} \xi \xi \varsigma, x p \hat{\alpha} \sigma \iota \varsigma\right)$ of bodies takes place when a body receives certain qualities of another, while remaining, nevertheless, itself, or both mixed bodies

1 The article was prepared within the framework of the Basic Research Program at the National Research University Higher School of Economics (HSE) and supported within the framework of a subsidy by the Russian Academic Excellence Project '5-100'.

2 Alexander of Aphrodisias, De mixtione IV, XII; Alexandri Aphrodisiensis praeter commentaria scripta minora, Ed. I. Bruns, Berlin, 1892, pp. 218.1-3, 227.11-228.4. 
acquire the qualities of each other preserving their own natures. While in the case of conflation ( $\sigma \dot{\gamma} \gamma \chi \cup \sigma(\varsigma)$, bodies lose their identity as they establish a new junction, and in composition ( $\pi \alpha \rho \dot{\alpha} \theta \varepsilon \sigma \varsigma \zeta)$, they just externally contact with each other. The blending with preservation of the mixed bodies' nature has been grasped by the Stoics as total blending ( $\left.x p \hat{\alpha} \sigma \iota \varsigma \delta \iota^{\prime} \partial \ddot{\lambda} \omega \nu\right),{ }^{3}$ that is, such that one body penetrates into another completely and totally. As the tradition testified by Stobaeus asserts, for the mixture, the Stoics distinguished $x p \alpha \sigma \sigma \varsigma \varsigma$ as applied to liquids and $\mu i \xi ı$ for non-liquids (it was the $\mu \hat{i} \xi ı$ s type of mixture that Stoics demonstrated through the example of iron and fire). ${ }^{4}$

The principle of total blending has been exemplified by Stoics through the examples of mixture of wine with water, penetration of soul into body, ${ }^{5}$ piercing the air by light, ${ }^{6}$ as well as the example of iron incandescent by fire. In the last case, an iron item purchases the properties of fire (burning), with preserving its nature of iron.

The Stoic teaching on blending, whereby the mixed bodies retain their identity, was apprehended and actively applied by Christian authors.

Generally, the examples of total blending of physical bodies forwarded by Stoics have a natural ability to illustrate two possible cases. These are, to call them so, the cases of symmetrical and asymmetrical impartation of properties. The example of mixing wine with water serves as an illustration for the case of symmetrical impartation of properties: for here each of two existing things acquire the properties of another, like wine takes the properties of water and water take those of wine. As for such examples like that of penetration of fire into iron and of piercing the air by light, these are the cases where one item accepts the properties of the another, whereas the latter does not accept the properties of the former (iron takes the properties of fire and air takes those of light, but not vice versa).

It is possible to specify two close, though not identical, interpretative lines in the Byzantine theology for the topic of penetration of fire into iron, along with the adherent references to the Stoic natural philosophy. One of these lines concerned the necessity of pointing to something combining within itself simultaneously two and one realities (which is a philosophical prerequisite of the Chalcedonite Christology). The other displayed the case when something receives into itself the properties of the other ("of better nature"). In this case,

3 As a technical term, the notion of total blending has been mostly in use.

4 Joannes Stobaeus I, 17, 374-377; Ioannis Stobaei Eclogarum. Physicarum et Ethicarum. Vol. 1. Lipsiae, 1869, p. 102.

5 Ibid. The background of this example is a prerequisite specific for the Stoic doctrine that everything existing is corporeal.

6 For ex.: Alexander of Aphrodisias, De mixtione IV; Alexandri Aphrodisiensis, p. 218.9-10. 
through the example of penetration of fire into iron, as a rule, it was the asymmetrical topic to be illustrated: when the properties of one item are received by the other but the former does not receive the properties of the latter, ${ }^{7}$ and even, in particular, when own properties of an item receiving the properties of another one cease to manifest themselves and cover themselves under the received properties. The latter happened, as we'll see, when the example of burning iron (and of air pierced by light) served to illustrate the penetration of the uncreated into the created. These two interpretative lines often converged in one and the same case, like it used to be in the Chalcedonite Christological literature.

Thus, generally, in Byzantine theological literature the example of fire and iron has been usually applied within a narrative of two diverse natures interacting between each other so that they form a unity in one way or another (in regard to hypostasis for Christ; in regard to powers, properties or energies for the other cases). Depending on the objectives standing before one or another Byzantine writer, by giving this example, some writer emphasized the difference of interacting natures and thus activated its distinctive potential, others acted the opposite way and employed its uniting potential as we'll see further.

Once we make an attempt to typologize the objectives of using the fire and iron example in the Byzantine theology as a bearer of above listed connotations, it should be resumed following way. First, it has been applied to represent the conjunction of two natures of Christ in one hypostasis and to clarify the specifity of communication of these natures. Second, as an example illustrating theosis: when the divine properties become familiar to the deified human being. Third, for depiction of the mode of unification with God for the angelic powers. And, fourth, after the Ancient philosophical tradition, - for depiction of penetration of soul into a body of a human being.

7 Here the philosophical sense implied in the example of iron and fire coincides with that contained in the concept of participation, precisely, in the Platonic version thereof (as distinct from Aristotelian one). To say more, as will be shown below, the topic of penetration of fire into iron and the concept of participation have been historically overlapped in the texts of Byzantine theologians (see the sections of the present article concerning Basil of Caesarea and Cyril of Alexandria). A number of my papers was devoted to typologizing implications of the concept of participation in the Byzantine theological and philosophical thought and to tracing the deflections of the concept in the writings of selected Byzantine authors. Here I will just point out that the Platonic sense of the concept of participation is displayed in that the participated being becomes an ontological cause of a certain property for the participated being. Cf. for ex: D. Biriukov, "Paradigms of Participation in Origen," Scr 13 (2017), pp. 278-279. 
The following will be an attempt to cast a light on the senses, which different Byzantine theologians supposed by using this example.

Origen. For the first time, the example of iron penetrated by fire emerges in Origen. Origen showed thereby the way of conjunction of Logos with Christ's soul. According to Origen, just like the burning iron accepts the qualities needed for the nature of fire: light and heat, - the same way the soul of Christ is presented in God: everything it thinks, feels and performs, is God. This interpretation is featured in the second book of the treatise On the First Principles:

ferri metallum capax est et frigoris et caloris ; si ergo massa aliqua ferri semper in igne sit posita, omnibus suis poris omnibusque uenis ignem recipiens et tota ignis effecta, si neque ignis ab ea cesset aliquando neque ipsa ab igne separetur : numquidnam dicemus hanc, quae natura quidem ferri massa est, in igne positam et indesinenter ardentem posse frigus aliquando recipere? Quin immo (quod uerius est) magis earn, sicut in fornacibus saepe fieri oculis deprehendimus, totam ignem effectam dicimus, quia nec aliud in ea nisi ignis cernitur; sed et si qui contingere atque adtrectare temtauerit, non ferri, sed ignis uim sentiet. Hoc ergo modo etiam ilia anima, quae quasi ferrum in igne sic semper in uerbo, semper in sapientia, semper in deo posita est, omne quod agit, quod sentit, quod intellegit, deus est.

The metal iron is capable of cold and heat. If, then, a mass of iron be kept constantly in the fire, receiving the heat through all its pores and veins, and the fire being continuous and the iron never removed from it, it become wholly converted into the latter; could we at all say of this, which is by nature a mass of iron, that when placed in the fire, and incessantly burning, it was at any time capable of admitting cold? On the contrary, because it is more consistent with truth, do we not rather say, what we often see happening in furnaces, that it has become wholly fire, seeing nothing but fire is visible in it? And if any one were to attempt to touch or handle it, he would experience the action not of iron, but of fire. In this way, then, that soul which, like an iron in the fire, has been perpetually placed in the Word, and perpetually in the Wisdom, and perpetually in God, is God in all that it does, feels, and understands. ${ }^{8}$

8 Origen, De princ. II, 6, 6: 181-195, Origène, Traité des principles, Tome I (Livres I et II), Trad. par H. Crouzel et M. Simonetti, (SC 252), Paris, 1978, p. 321; Ante-Nicene Fathers, vol. 4, Transl. by F. Crombie, ed. by A. Roberts, J. Donaldson, and A. Cleveland Coxe, New York, 2007, p. 283. 
By the example of penetration of fire into iron, Origen here demonstrates, first, that the soul of Christ is entirely penetrated with divine properties and accepts them; second, that as the heated iron becomes a source of heat and light, the soul of Christ is a source of divine heat for people; and third, giving an example where the iron is always in fire, Origen postulates immutability of unity of Christ's soul with God. Attention should be paid to Origen's words about the iron as being totally penetrated by fire: the combination of the example provided by the Stoics with the notion of totality allows to affirm that here we are observing the connotations to the concept of total blending in its technical meaning. ${ }^{9}$

This Origen's example pointing at the union of Christ's soul to God through the image of penetration of fire into iron has become - as displaying the penetration of the uncreated into the created - paradigmatic and influenced shaping two of the above mentioned interpretative ways of the Stoic topic of mixture in the Byzantine literature at a time: when the image of burning iron was employed within the Christological context, ${ }^{10}$ and when it was taken for a description of theosis of a human being.

Prior to pass to the material on the latter type of interpretation, I would put down something about the reaction of Cappadocian authors on the mentioned Origen's example.

Cappadocians. While advocating the Nicaean doctrine of consubstantiality of the Son with the Father and clashing with Arianism/Anomoeanism in the person of Eunomius, Cappadocian theologians have rejected the comparison of Christ's communion with God and the penetration of fire into iron made by Origen. Gregory of Nyssa argued that the nature of iron essentially distinguishes from that of fire due to the fact that iron in its natural state is cold, and it means that the comparison of the conjunction mode of Christ-Logos and God the Father with that of iron and fire is not correct.11

$9 \quad$ It also has sufficient meaning that while giving the example of burning iron, Origen, probably for the first time in Christian literature, represents the conception of communicatio idiomatum (here in the sense of conveyance of divine properties to Christ's soul), naturally, still in germinal and not explicated way. Cf.: R. Williams, Arius. Heresy and Tradition, London, 1987, p. 145 .

10 I will not consider here the fire and iron example within the Christological context. I would just point out that this topic, as illustrating the co-existence of divine and created natures in Christ, became widespread in the Byzantine theological texts after times of the Cappadocians.

11 Gregory of Nyssa, C. Eun. I, 1, 284, Gregorii Nysseni opera. Contra Eunomium Libri I et II, pars prior, Ed. W. Jaeger, Leiden, 196o, p. 110.9-14. Brief discussion on the issue: M. Barnes, "Eunomius of Cizicus and Gregory of Nyssa: Two traditions of Transcendental Causality." Vigiliae Christianae, 52 (1998), pp. 76-77 \& note 75 . 
Nevertheless, the very example of heated iron used by Origen as an illustration of penetration of the uncreated into the created, was seized by the Cappadocians and became being applied by them probably in the Christological context, $^{12}$ as well as to illustrate perceiving divine properties by the angelic powers. It might be asserted that Basil of Caesarea has applied the paradigm Origen had used to describe the relation of Christ's soul with the deity to that of the deity and the angels.

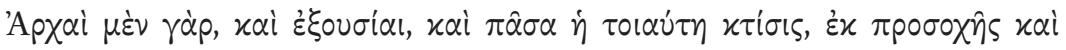

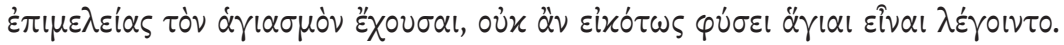

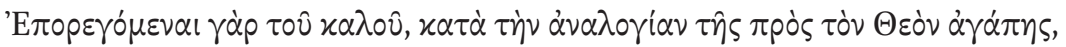

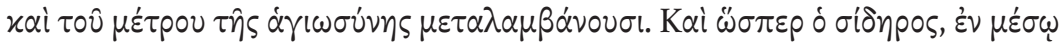

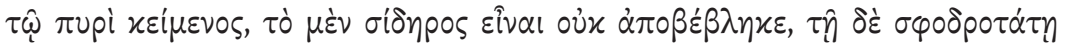

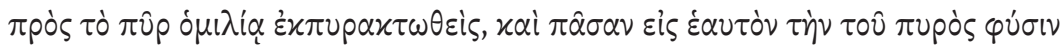

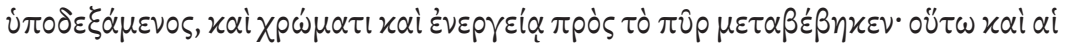

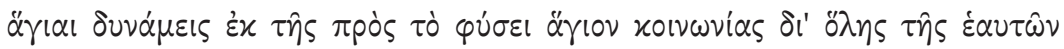

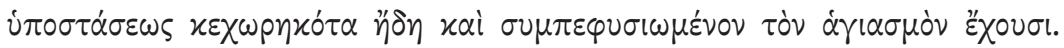

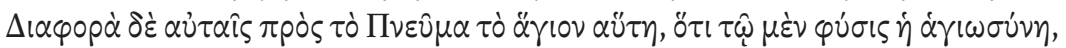

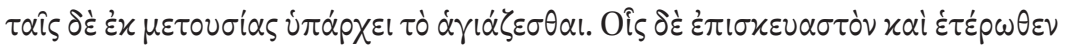

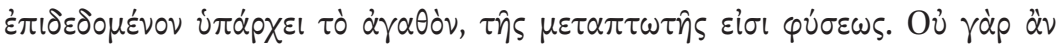

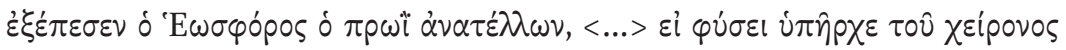

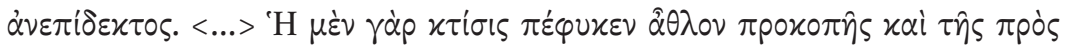

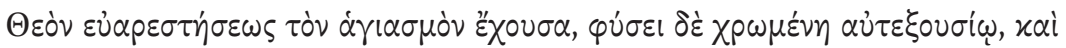

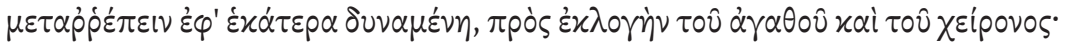

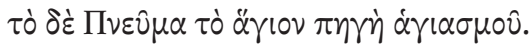

$<\ldots>$ It would make no sense to say that the principalities and powers and all such creatures, which have holiness from diligence and attention, are holy by nature. After all, yearning for the good, they receive a measure of holiness proportionate to their love for God. Furthermore, when iron is placed in the middle of fire, while it does not cease to be iron, it is nonetheless inflamed by the intense contact with the fire and admits the entire nature of fire into itself. And so in both outward appearance and activity the iron is transformed into fire. Likewise, the holy powers, from their communion with that which is holy by nature, possess a holiness that pervades their whole subsistence, and they become connatural with that which is holy by nature. The holy powers and Holy Spirit differ in this 
regard: for the latter, holiness is nature, whereas for the former, being made holy comes from participation. Those for whom the good is adventitious and introduced from another possess a nature that can change. Indeed, Lucifer who rises at dawn would neither have fallen $<\ldots .>$ if by nature he was not capable of admitting that which is worse. $<\ldots>$ It is the nature of creation to have holiness as the prize for its progress and for becoming well-pleasing to God. By its nature it employs selfdetermination and is capable of moving itself toward either direction by choosing the good or the bad. But the Holy Spirit is the source of holiness. ${ }^{13}$

In the context of controversy with the Anomoeans who used to deny the divinity of the Holy Spirit and affirmed that his nature is similar to the nature of angels, Basil of Caesarea here differentiates the angelic powers with no sanctity by their nature and the Holy Spirit, the source and bearer of sanctity by nature. Like that the fire penetrates into iron, the Holy Spirit sanctifies the angelic powers and totally penetrates into their nature, owing to what the angels accept by participation the sanctity natural for Spirit. The speech about total penetration of the angelic nature by the Spirit in the context of iron and fire example again contains connotations referring to the Stoic concept of

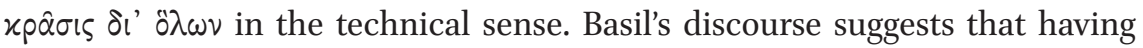
accepted the sanctuary of Spirit through the good intentionality of will, the angelic powers become similar to the Spirit by their properties - like burning iron accepts the properties and energies of fire. We can discern between the nature of the Spirit and one of the angelic powers due to the knowledge of etiology, background of these natures: angelic powers, being changeable and autocratic by nature, had the opportunity to choose good or evil, and they chose the good and implication to Holiness. The Spirit is good and holy by nature, in eternity, and therefore it is impossible to speak of him as one who chose good and holiness. As we see, here, with the wish to discern precisely the orders of being for angels, on one hand, and the Holy Spirit, another, Basil actualizes the distinctive potential of the discussed example.

Cyril of Alexandria. It was namely this passage from Basil whereupon Cyril of Alexandria leaned in the course of his polemics against the Arians (especially in: Theasurus, PG 75, col. 593A-B). Cyril introduces the topic of iron and fire to

13 Idem, C. Eun. III, 2, 29-53: PG 29b, col. 66o, Basile de Césarée, Contre Eunome, suivi de Eunome, Apologie, T. 2, Ed. B. Sesboüé, G. de Durand, L. Doutreleau, (SC 305), Paris, 1983, pp. 152-154; St. Basil of Caesarea, Against Eunomius, Transl. by M. DelCogliano and A. Radde-Gallwitz, Washington, 2011, p. 188. Cf. Idem, De Spir. XxvI, 63: PG 32, col. 184B, Basile de Césarée, Sur le Saint-Esprit, Intr., texte, trad. et notes par B. Pruche, (SC $17 \mathrm{~b})$, Paris, 1968, pp. 472-474. 
distinguish the created and uncreated natures. To gain this, Cyril, quite similarly to Basil, operates with the categories of by nature - by participation, where the participation is taken in the Platonic sense, ${ }^{14}$ while referring these categories with the topic of fire penetrating into iron: the latter has the properties by participation which fire possesses by its nature. According to Cyril, the Son and the Spirit are holy and are the Deity by nature; while "we" join to God by participation like the iron being penetrated by fire and acquiring its properties. ${ }^{15}$

In this context, Cyril starts using technical, philosophical language. He says in Theasurus that the properties come out indivisibly from substances and thus are transferred to the other substances gaining the unity by participation with the first substances in regard of these properties. This is the way the heat comes out of fire, sweetness from honey, freshness from water. ${ }^{16}$ Cyril speaks of that in his Commentary on St John's Gospel with giving an example of fire conveying its heat to iron and wood, and also that of grammar and geometry, through learning which a human being acquires the name of, respectively, grammarian and geometer. While speaking of this, Cyril resorts to the discourse of designation: fire is hot by nature, while burning iron and wood are called hot once they participate in fire and receive from it the power of heat naturally improper for them; nonetheless, they are not called fire, In a similar way, a grammarian and a geometer are named by the science which they have learned, respectively, grammar ad geometry; nonetheless, they are neither grammar, nor geometry.

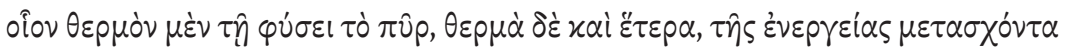

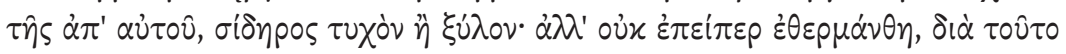

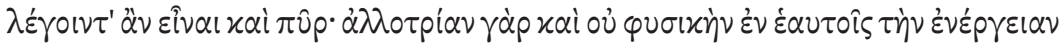

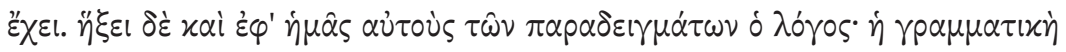

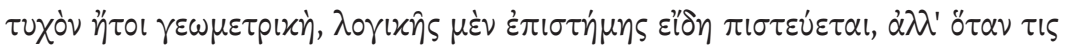

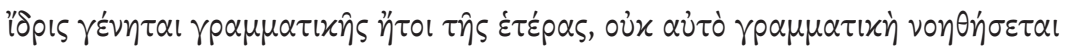

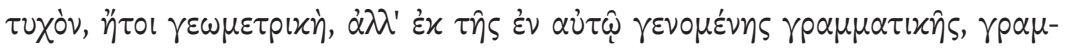

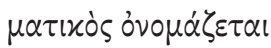

As fire is hot by nature, and other things too are hot, by partaking of its operation, as iron or wood: but not because they are heated, are they said to be fire: for they have an external and not a physical operation in them.

14 See above, note 7.

15 Cyril of Alexandria, Theasurus, PG 75, col. 200A.

16 Ibid., 593B. 
But our argument will proceed by means of illustrations in regard to ourselves too. Grammar for instance, or Geometry, are held to be species of reasoning science, but when any one becomes skilled in grammar or the other, he is not himself conceived of as Grammar or Geometry, but from the Grammar that is in him, he is called a Grammarian. ${ }^{17}$

Evidently, this discourse of designation, advanced by Cyril of Alexandria, responds to the elementary procedure of predicating, where one thing is predicated by a property specific for another. ${ }^{18}$

Therefore, the example of burning iron as an illustration of the specificity of penetration of uncreated into created is developed in a following way by Cyril of Alexandria comparatively to Basil of Caesarea's interpretation of it: first, instead of angels as the created beings, of which Basil has spoken, Cyril is narrating on "us", i. e. human beings; second, Cyril scholasticizes the issue by introducing the notions of nature (substance), properties and designation.

Ps.-Macarius. The topic of fire and iron can be also found in anthropological and ascetical literature of that period: in writings of Gregory of Nyssa, of the author of the Macarian corpus, of Abba Isaiah ${ }^{19}$ etc. The author of the Macarian corpus reveals acquaintance with the Ancient natural philosophical concepts of mixture: he speaks of confusion of evil with a human not by the

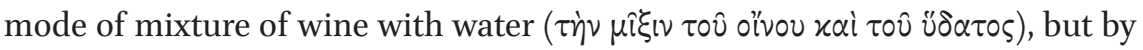
that of wheat and tares, growing on the same field, or of presence of a robber and a house owner in one habitation. ${ }^{20}$ Ps.-Macarius contraposes here a mixture of physical bodies - which is grasped in the sense of the Stoic total blending (testified by the classic Stoic example of mixture of wine and water, as well as the context wherein the theologian lays down the example) - to an external composition of elements. According to the author, the evil is presented

17 Idem, Comm. in Joan. IV, 3, 57, Sancti patris nostri Cyrilli archiepiscopi Alexandrini in D. Joannis evangelium, ed. P. Pursey, vol. 1, Oxford, 1872, p. 541; Commentary on the Gospel according to S. John by S. Cyril Archbishop of Alexandria, vol. I, S. John I-VIII, Oxford, London, 1874, p. 427 .

18 Within the framework of Aristotelian conceptual network, a property/predicate, on which Cyril here argues, correlates with a property/natural faculty, whereof Aristotle speaks in Cat. 9a14-24. Such a property/natural faculty is distinct from substance, but also is not an accidental and transient property. It naturally belongs to the item whence it comes (like heat belongs to fire).

19 Marcus Plested draws attention to the likeness of writings of Abba Isaiah and Ps.-Macarius in this as well as in some other aspects, see: M. Plested, The Macarian Legacy. The Place of Macarius-Symeon in the Eastern Christian Tradition, Oxford, 2004, pp. 184-185.

20 Hom. Xlvi, 2, Sancti Patris Nostri Macarii Aegyptii (Symeonis Mesopotamitae) Sermones ascetici et epistulae. Collectio I, Ed. ab A. Danuvio et V. Desprez, Moscvae, 2014, p. 579. 
in a human right in an external way, not mingling with the human essence entirely.

As for the topic of penetration of fire into iron, along with addressing it in an eschatological perspective, ${ }^{21}$ Ps.-Macarius involves it for the description of theosis. In this projection, he affirms that a human being united with God modifies his proper properties to those divine ones, the same way as the iron loses its natural rigidness and becomes soft under the heat of fire:

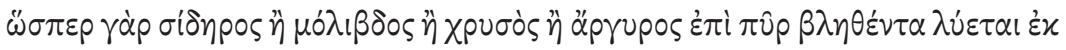

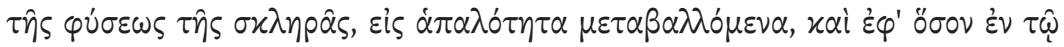

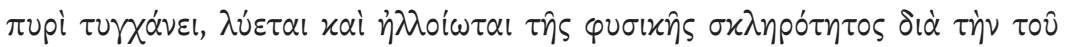

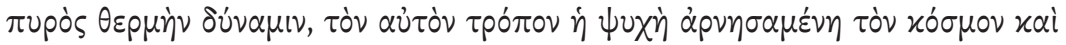
$\tau o ̀ v ~ x u ́ p l o v ~ \mu o ́ v o v ~ \pi 0 \theta \dot{\eta} \sigma \alpha \sigma \alpha$.

Just as iron or lead or gold or silver, if thrown into fire, will melt and be transformed from its natural hardness to a soft substance, and as long as it remains in the fire becomes all the more a molten liquid, losing its natural hardness because of the powerful heat of the fire, the same is true for the soul that has turned away from the world in its desire for the Lord alone. ${ }^{22}$

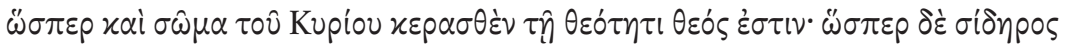

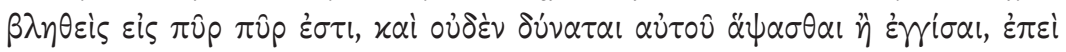

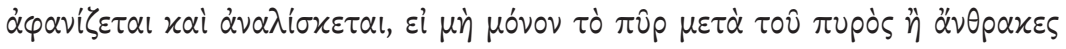

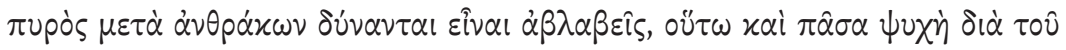

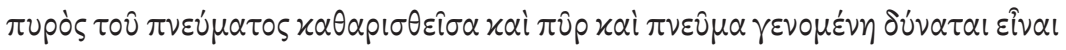

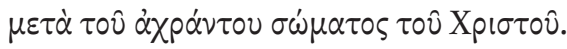

Like the body of Christ, being mingled with the deity, is God; like iron cast into fire is a fire, and nobody can touch or approach to it without fearing to be eliminated or extinguished (only fire with fire and heated coal with heated coal may remain unhurt), - the same way any soul purified by the

Hom. XV, 10, Die 50 geistlichen Homilien des Makarios, Her. und erl. H. Dörries, E. Klostermann and M. Krüger, Berlin, 1964, S. 132.

22 Hom. IV, 14: 214-220, Die 50 geistlichen Homilien des Makarios, S. 37; Pseudo-Macarius, The fifty spiritual homilies and the Great Letter, Transl. by George A. Maloney, New York, 1992, p. 55 . 
fire of the Spirit and having become itself fire and spirit, can be together with the pure body of Christ. ${ }^{23}$

Like in Origen, a human soul is compared here with the burning iron; but certainly, the Christology represented in the latter fragment is quite different from that of Origen. The human soul of the iron and fire example by Ps.-Macarius is not the soul of Christ as it has been given by Origen, but the soul of the deified man. Ps.-Macarius similarizes the union of soul with God to the penetration of fire into iron and to the incarnation of Christ, of which he also speaks using the terms of mixture. The presence of the issue of incarnation in this fragment admits to specify here the echo of the tantum quantum principle, that is, inasmuch as God became man, man becomes a God. This principle is expressed in the above-cited passage in the following way: as in the incarnation (and in the Eucharist), there is a mixture of the Body of Christ with the deity, so that the Body is the very deity, so the purified human soul unites with the Holy Spirit and becomes spirit. With that, the pattern of penetration of fire into iron stands as the principal exemplification for all these topics, having the Stoic natural philosophy behind itself as a background. The author of Macarian corpus activates here namely the uniting potential implied in the example: he says that the iron penetrated by fire is the fire, as well as the Body of Christ mingled with deity is God, and the human soul purified by the fire of the Holy Spirit is spirit. Therefore, the words of Ps.-Macarius about conjunction of the created nature with the uncreated one come dangerously close to a suggestion that the created dissolves within the uncreated. In spite of that, to my mind, the connotations encompassed in the represented example with fire and iron, backed by the Stoic natural philosophical prerequisites, point at the understanding, compliant to which the created does not extinguish but purifies itself and transfigures when unified with the uncreated, being satiated by its properties.

Here we detect a cardinal diversity of Ps.-Macarius' and Cyril of Alexandria's approaches. Both authors utilized the example with iron and fire to reveal the relation of created and uncreated natures, where the fire responds to the uncreated and the iron to the created natures. At this point, differently from Ps.Macarius, who speaks of iron penetrated by fire as of fire, Cyril, by activating the distinctive potential of the example, insisted on that the iron incandescent by fire is not called fire. This divergence between the approaches of two theologians could be explained by that Cyril used the fire and iron example within

23 Hom. LII, 6: f. 213, Macarii Anecdota. Seven unpublished homilies of Macarius, Ed. by G. Marriott, Cambridge, London, 1918, p. 27. 
the frame of dogmatic thought dealing with distinction of notions, whereas Ps.-Macarius did it staying inside the ascetic and mystical tradition.

Maximus the Confessor. The example of penetration of fire into iron taken in the context of penetration of the uncreated nature into created one is brightly exposed in the thought of Maximus the Confessor. Maximus writes in the Ambigua to John:

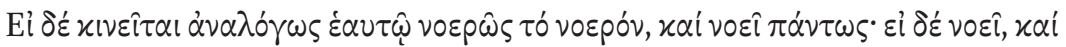

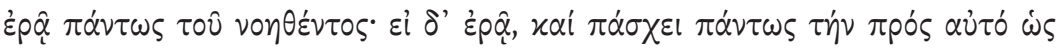

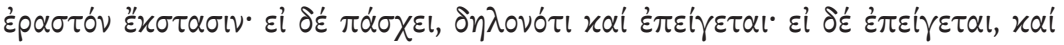

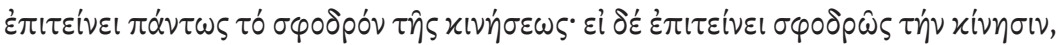

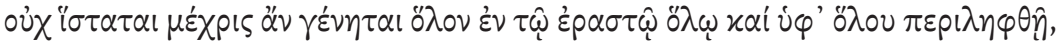

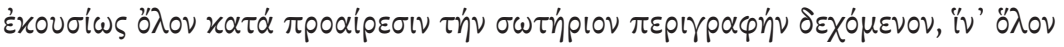

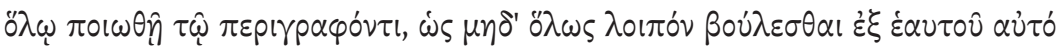

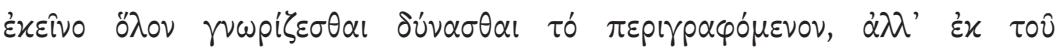

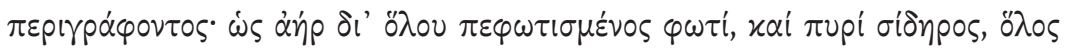

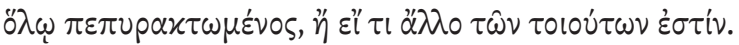

If an intellective being is moved intellectively; that is, in a manner appropriate to itself, then it will necessarily become a knowing intellect. But if it knows, it surely loves that which it knows; and if it loves, it certainly suffers an ecstasy toward it as an object of love. If it suffers this ecstasy; it obviously urges itself onward, and if it urges itself onward, it surely intensifies and greatly accelerates its motion. And if its motion is intensified in this way; it will not cease until it is wholly present in the whole beloved, and wholly encompassed by it, willingly receiving the whole saving circumscription by its own choice, so that it might be wholly qualified by the whole circumscriber, and, being wholly circumscribed, will no longer be able to wish to be known from its own qualities, but rather from those of the circumscriber, in the same way that air is thoroughly permeated by light, or iron in a forge is completely penetrated by the fire, or anything else of this sort. ${ }^{24}$

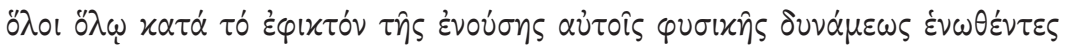

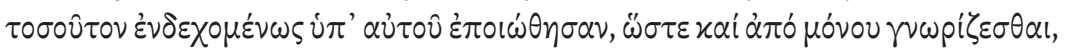

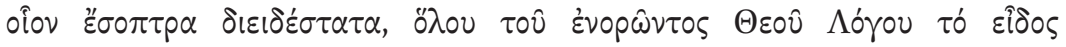

24 Amb. vir: PG 91, col. 1073C-1076A; Maximus the Confessor, On Difficulties in the Church Fathers. The Ambigua, Ed. and transl. by N. Constas, Vol. 1, Cambridge, London, 2014, pp. $87-88$. 


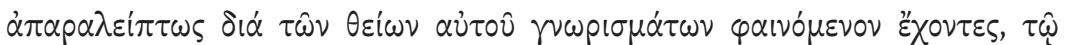

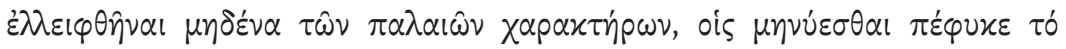

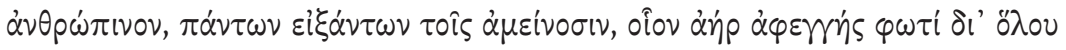

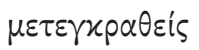

Having been wholly united with the whole [Word], within the limits of what their own inherent natural potency allows, as much as may be, they were imbued with His own qualities, so that, like the clearest of mirrors, they [the saints] are now known only as reflections of the undiminished form of God the Word, who gazes out from within them, for they possess the fullness of His divine characteristics, yet none of the original attributes that naturally define human beings have been lost, for all things have simply yielded to what is better, like air - which in itself is not luminous - completely mixed with light. ${ }^{25}$

Maximus suggests that the saints who are entirely penetrated by the entire divinity and suffer an impartation of properties from the divine, accept the divine properties so that hereafter they are both recognized by them and become conscious of themselves over these properties, while, nevertheless, not being deprived of their own created nature. ${ }^{26}$ It should be noticed that Maximus uses here the Stoic terminology: he speaks of the total blending of air with light, and, similarly to the Stoics, ${ }^{27}$ he applies the example of air penetrated by light equally and in the context of the same natural philosophical connotations as the fire and iron example. ${ }^{28}$

As for the conceptual level, we see here the same consequence as in the thought of the author of the Macarian corpus. Like Ps.-Macarius, Maximus promotes the uniting potential of the fire and iron example (as well as of that of air and light) and asserts that the deified human being is recognized not by human, but by the divine properties which he acquires in uniting to the deity.

With that, while evolving the line of Ps.-Macarius, Maximus takes a step allowing him to unfold the uniting potential of the metaphor of burning iron as referring to the penetration of the uncreated nature into the created one with avoiding the peril of interpreting his thought in the sense that the created would dissolve in the uncreated. Whether consciously or unconsciously, he introduces reflection into his narrative and employs the cognition/recognition

25 Ibid., col. 1137B11-C6; Ibid., p. 213, slightly revised.

26 Cf. P. Sherwood, The Earlier Ambigua of S. Maximus the Confessor and his Refutation of Origenism, Roma, 1955, p. 151.

27 See Alexander of Aphrodisias, De mixtione IV; Alexandri Aphrodisiensis, pp. 217.32-218.11.

28 See Ibid. 
phraseology, - that is the point where his discourse essentially differs from the ontologizing language of Ps.-Macarius. Actually, Maxim utilizes the image of a mirror (implying that a deified man reflects in himself the divine properties), and says that a saint is cognized and recognized by the properties of deity presented in him like enlightened air and incandescent iron which are recognized by the natures penetrating into them, respectively light and fire. At the same time, Ps.-Macarius affirms that the human soul purified by the fire of the Holy Spirit is spirit, as well as the iron penetrated by fire is fire.

John Damascene. After Maximus the Confessor, the topic of penetration of fire into iron in the context of depiction of theosis is seemed to retain its connection with the discourse of cognition established by Maximus. One can find it in the writings of John Damascene and Symeon the New Theologian.

Damascene involves this topic in the third Apologetic Treatise against those Decrying the Holy Images:

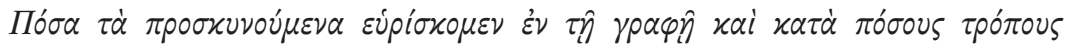

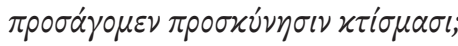

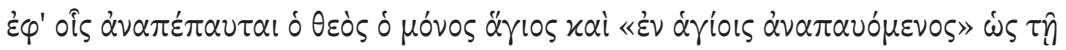

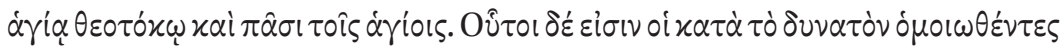

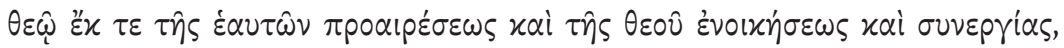

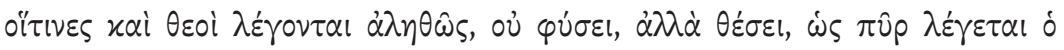

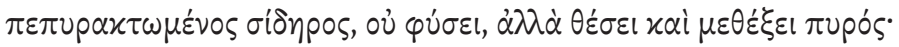

What we find worshipped in Scripture, and in how many ways we show worship to creatures.

First, those places in which God, who alone is holy, has rested, and His resting-place in the saints $[I s .57,15]$, as in the holy Mother of God and in all the saints. These are they who have become likenesses of God as far as possible, of their own free will, and by God's indwelling and synergy. They are truly called gods, not by nature, but by establishment, just as red-hot iron is called fire, not by its nature, but by establishment and participation in the action of fire. ${ }^{29}$

Here Damascene, within the frame of the Iconoclastic controversy, speaks of worship of the saints. In this connection, he specifies what does it mean to be a saint and engages for that the notion of likening to God, the doctrine on free

29 John Damascene, De imag. III, 33: 1-11, Die Schriften des Johannes von Damaskos, vol. 3, Ed. B. Kotter, Berlin, 1975, S. 137 . 
will and synergy and the example of iron incandescent by fire. Within this, Damascene uses the opposition by nature - by establishment / participation..$^{30}$

There is a sort of accumulation of various lines in this Damascene's passage which we have discovered in connection with the iron and fire example to appear in the previous Byzantine authors' writings. For instance, of the topics represented in this fragment, there is the theme of free will that we have met in the fragment of Basil, while Cyril applied the opposition by nature - by participation and the topic of participation of incandescent iron in fire serving as an illustration of impartation the properties of fire into iron. Maximus' topic of cognition / recognition by the "better nature" (the iron penetrated by fire is acknowledged by the properties of fire and the saint by the properties of deity which he has received) is transformed here into the topic of naming: the iron incandescent by fire is named fire, while a godly man is named god (by establishment or by participation).

That is, similarly to Ps.-Macarius and Maximus the Confessor, John Damascene employs the uniting potential of fire and iron example. However, like Maximus, he turns away from a "naive" ontologizing language used by Ps.-Macarius which points at the unity of the conjoining natures. What he turns to, is the discourse where this unity is interpreted as a phenomenon manifested for our intellectual abilities, which supposes an indication of unity in some respect and preserves from an understanding of this in the sense of conflation of the unified natures (i. e. a merge of the created nature with uncreated one).

Simeon the New Theologian. The last Byzantine author to be observed in this review is Symeon the New Theologian. In his 3o-th hymn, Symeon describes the conjunction of his soul with God in following way:

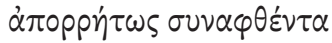

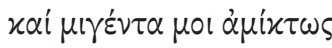

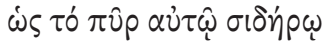

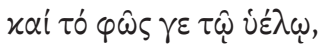

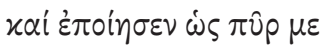

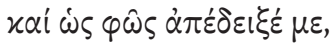

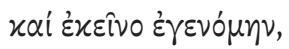

30 The expressions by establishment and by participation are used here by Damascene in a synonymic way. Regarding the opposition by nature - by establishment cf.: D. Biriukov, "The Strategies of Naming in Polemic between Eunomius and Basil of Caesarea in Context of Antic philosophical Tradition," Scr 4 (2008), pp. 108, 116-120. On the opposition by nature (substance) - by participation see: Idem, "On the Topic of Participation in the Divine Essence according to St Symeon the New Theologian in the Patristic Context," Scr 11 (2015), pp. 295-305. 


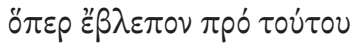

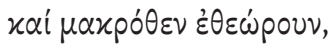

[He] unspeakably joined, and mixed in me without mixing,

like the fire in the iron itself, and the light in the glass, and He made me like a fire, and made me like light, and I became that which I had seen before and had contemplated from afar. ${ }^{31}$

A little further, Symeon, while speaking of communion in Christ's Body and Blood, describes this as follows:

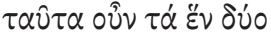

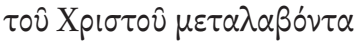

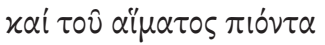

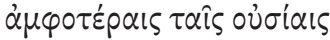

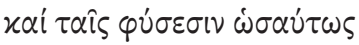

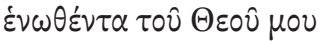

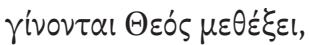

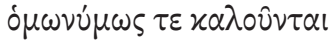

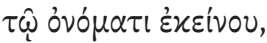

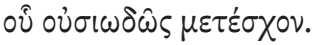

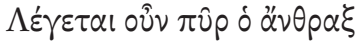

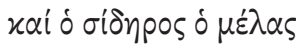

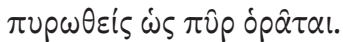

Therefore [body and soul] are one and two

partaking of Christ

and drinking his blood,

united to both essences,

and likewise to both

$31 \quad H y m n$ xxx, 425-433, Symeon der Neue Theologe, Hymnen, Prol. und krit. text, besorgt. A. von Kambyles, Berlin, 1976, S. 280-281; Divine Eros. Hymns of St Symeon the New Theologian, Transl. and introd. by D. Griggs, New York, 2011, slightly revised. 
natures of my God;

they become God by participation,

and they are called by the same name,

by his name;

they have participated in God's essence. ${ }^{32}$

And so it is said that charcoal is fire,

and iron is black;

when it is burned it looks like fire.

So if it appears as such,

it would also be called as such,

seen as fire, it is called fire. ${ }^{33}$

In the 44-th hymn, Symeon once again addresses to the topic of penetration of fire into iron to expose the conjunction of man with God through the gifts of the Holy Spirit:

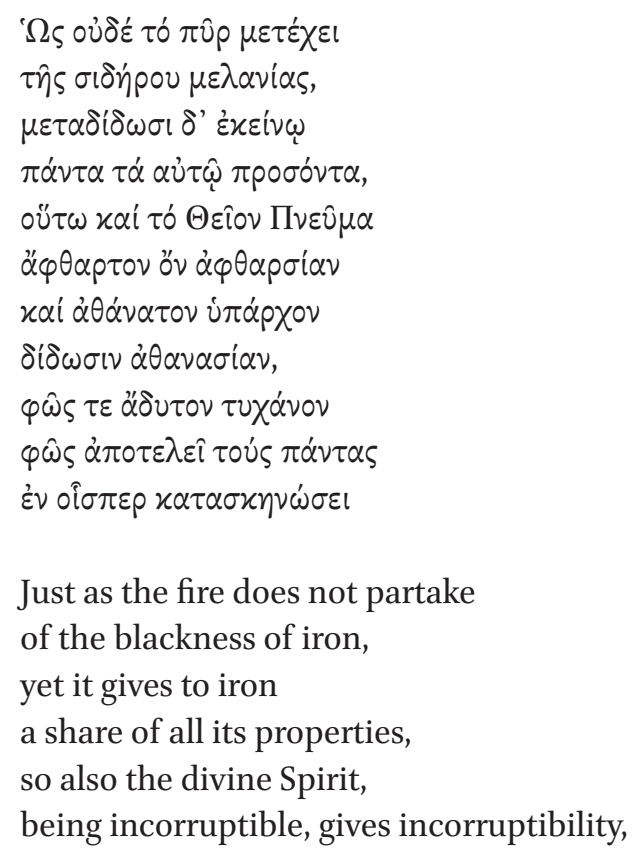

\footnotetext{
32 About the theme of participation in the divine essence in Symeon the New Theologian and other Patristic authors, see: D. Biriukov, "On the Topic of Participation in the Divine Essence."

Ibid., 478-493, Symeon der Neue Theologe, Hymnen, S. 282; Divine Eros.
} 
and being immortal,

He gives immortality,

and being never setting light,

He turns everyone into light

in which He shall pitch his tent. ${ }^{34}$

Apart from the previously revised authors, Symeon, talking about conjunction with God through applying the topic of iron and fire, speaks from the first person and thus his narrative has the most expressive existential traits. In depicting his uniting to God, Symeon likens himself to the iron penetrated by fire and receiving its qualities, and also to the glass pierced by light. It should be noted that when Symeon, in the context of the fire and iron example, is utilizing the expression $\mu \iota \gamma \varepsilon \dot{v} \tau \alpha \mu$ o $\alpha \dot{\mu} i x \tau \omega \varsigma$, or "mixed in me without mixing," with the use of derivatives from $\mu$ ir $v \mu_{\mu l} / \mu i \xi \xi \zeta$, a repercussion of Stoic natural philosophical terminology takes place here, wherein, as I have mentioned, the

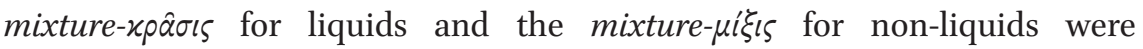
distinguished, provided that the Stoics used to illustrate the latter right by the example of iron and fire.

In a conceptual way, Symeon is following here the line of Ps.-Macarius and Maximus. Like the latter, Symeon activates the uniting potential of the iron and fire example in order to describe thus his acceptance of the divine properties bestowed to him by God. With that, Symeon articulates this topic in the closest way to that of Maximus. The latter, when speaking of how the saints receive the divine properties, uses the iron and fire, as well as air and light examples and emphasizes the sufferable mode of being of a deified man, which is expressed in his words that a deified man wishes to be recognized and determined by divine, but not his own human, nature. Like Maximus, Symeon speaks of the iron incandescent by fire along with of the glass pierced by light - similar to Maximus' example of air and light - and declares the ability of recognition and naming by the better (uncreated) nature for a man who unites to God. I believe it allows to state the influence of Maximus on Symeon in the considered aspect. ${ }^{35}$

It is remarkable that both Symeon (in Hymn xxx, 478-493) and Maximus (in Amb. VII: PG 91, col. $\left.{ }_{1073} \mathrm{C}-1076 \mathrm{~A}\right)$, when giving the example of iron and fire,

34 Hymn XLIV, 367-377, Symeon der Neue Theologe, Hymnen, S. 371; Divine Eros.

35 Other examples of the influence of Maximus' theology on that of Symeon's are discussed, in particular, in: D. Biriukov, "On the Topic of Participation in the Divine Essence", pp. 303305 . 
perform the same strategy. It is a strategy of recognition or discernment (almost in the scientific sense): we are able to recognize or discern the nature of fire displayed in iron through the properties revealed by incandescent iron, and, in a similar way, to discern the deified man as god (of small letter) through the demonstrated divinely features he is in possession of and bestowed to him by God. Or: we can conclude that human is god (of small letter) on the basis of that he shows himself as God.

Conclusion. I have considered the ways, through the example of penetration of fire into iron, whereby the Stoic natural philosophical paradigm of total blending was naturalized by the Early Christian and Byzantine theologians who intended to display the penetration of the divine into the created and the conjunction of the created with the divine, with the condition that the created does not dissolve in divine but remains within its own nature being penetrated by the properties of deity. The character of this paradigm ensures the presence of distinctive and uniting potentials within itself because it presupposes interaction of two natures remaining different but gathering into unity in a certain respect.

Like some other philosophical topics of great importance tied with the theological intuitions, it seems to have first appeared in the writings of Origen, who spoke of the conjunction of Christ's soul with God via the example of penetration of fire into iron. The further development of this topic by the Byzantine theologians comprised two principal lines presupposed in the Origen's operating with this example: these are Christological line and that of theosis. In the present article, I was interested mostly in the latter, along with the exposition of this topic within one more line - one can call it "dogmatizing," - which is also likely to have been impulsed by Origen. It takes the iron and fire example to clarify the distinctions in modes of existence for the created and the divine (in the course of polemics on the nature of the Holy Spirit; in the present article, I examined this line as represented by the Cappadocians and Cyril of Alexandria). Respectively, this dogmatizing line has made actual the distinctive potential of the fire and iron example. In its own turn, the line of theosis has exposed the uniting potential of the example (as we noticed that in the Macarian corpus, in the texts of Maximus the Confessor, John Damascene and Symeon the New Theologian).

The texts I have revised testify that this line developed from the more "naive" and ontologizing discourse of Ps.-Macarius to the discourse where the unity is spoken of as a phenomenon revealed for intellectual abilities, which suggests an indication of unity in a certain respect and preserves from interpreting this unity as a merge of unified natures. For the latter, one can distinguish the 
strategy of cognition / recognition, which Maximus the Confessor and Symeon the New Theologian adhered to. According to this strategy, by the properties displayed by incandescent iron, we can discern the nature of fire revealed in iron, and, in the same way, we can conclude that human is god (of small letter) on the basis of that he manifests himself as God, that is, exposes the divine features. 